\title{
Chemical and pharmacological investigation of micropropagated Hygrophila pogonocalyx produced from leaf explants
}

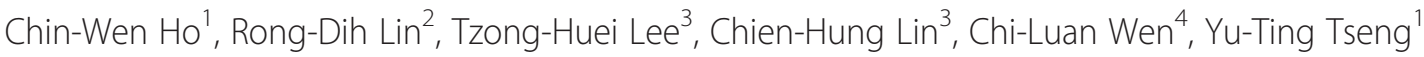 \\ and Mei-Hsien Lee L, $^{3 *}$
}

\begin{abstract}
Background: An optimized method for indirect shoot organogenesis from the leaf explants of Hygrophila pogonocalyx, a rare and endemic species in Taiwan, was developed to supply enough quantity of plant materials for the first chemical and pharmacological investigation.

Results: Incubation of the young leaves on Murashige and Skoog (MS) medium supplemented with 6-benzylaminopurine $(0.5 \mathrm{mg} / \mathrm{l})$ and indole-3-acetic acid $(0.1 \mathrm{mg} / \mathrm{l})$ resulted in the best multiplication rate for organogenesis. The average number of adventitious buds per leaf was $22.8 \pm 1.9$ after 8 -week culture. The adventitious buds rooted and developed into plantlets when cultured simply on MS medium. Using this protocol, up to 37,600 plants were produced from a single leaf explant in one year. From the ethanol extract of the leaves of this micropropagated plant, 13 compounds were isolated and identified, including two flavones $(1,11)$, four flavonols $(9,10,12$, and 13$)$, three phenylethanoid glycosides (6-8), two alkylated glycosides (2-3), and two steroids (4-5). Of these, acteoside (7) exhibited anti-tyrosinase activity in human epidermal melanocytes and luteolin 7-O- $\beta$-D-glucopyranoside (11) exhibited the greatest neurocytoprotective activity.

Conclusions: The method, indirect shoot organogenesis from leaf explants of $H$. pogonocalyx, could be developed to supply enough quantity of plant materials for the chemical and pharmacological investigation. In the present study, the isolated active compounds may develop for whitening agents or treating neurodegenerative diseases in the future.
\end{abstract}

Keywords: Anti-melanogenesis; Constituents; Hygrophila pogonocalyx; Indirect shoot organogenesis from leaf explants; Neurocytoprotection

\section{Background}

The extracts from plants of the Hygrophila genus (Acanthaceae) have been demonstrated to possess antitumor (Mazumdar et al. 1997), anti-bacterial (Khan and Omoloso 2002), hepatoprotective (Raj et al. 2010; Shanmugasundaram and Venkataraman 2006), free radical scavenging, anti-lipid peroxidation activities (Shanmugasundaram and Venkataraman 2006; Vijayakumar et al. 2006), and inhibit gentamicin-induced nephrotoxicity (Bibu et al. 2010). H. auriculata was reported to exhibit

\footnotetext{
* Correspondence: Imh@tmu.edu.tw

${ }^{3}$ Graduate Institute of Pharmacognosy, College of Pharmacy, Taipei Medical

University, Taipei 110, Taiwan

${ }^{5}$ Center for Reproductive Medicine \& Sciences, Taipei Medical University

Hospital, Taipei 110, Taiwan

Full list of author information is available at the end of the article
}

significant anti-diabetic activity in addition to potent antioxidant activity in diabetic individuals (Vijayakumar et al. 2006) and $H$. difformis exhibited significant protective activity against strychnine- and leptazol-induced convulsions (Pal and Samanta 2011).

Hygrophila pogonocalyx Hayata (Acanthaceae), a perennial aquatic water plant, is an endemic species in Taiwan (Hsieh and Huang 1974). Plant tissue culture techniques offer a viable tool for the mass multiplication of identical plant material and the germplasm conservation of rare endangered plants. These techniques can provide a continuous supply of plant materials from elite germplasm lines, which can help exploit the therapeutic properties of these plant species and eliminate the need for harvesting specimens from the wild. Thomas and 
Yoichiro (2010) standardized an in vitro propagation protocol for the rare medicinal plant Justicia gendarussa using nodal explants, and this improved method for plant regeneration is helpful for the study of phytochemical production (Balaraju et al. 2008; Sudha and Seeni 1994). Balaraju et al. reported an efficient regeneration protocol for a valuable medicinal plant, Vitex agnuscastus, and all regenerated plants exhibited high homogeneity (Vijayakumar et al. 2006).

In a previous study, tissue culture and plant regeneration via direct shoot organogenesis induced from the shoot tip or axially bud of $H$. pogonocalyx was reported (Huang and Win 1999). However, indirect shoot organogenesis from leaf explants has never been reported in this species. In our previous study, the $95 \%$ ethanol (EtOH) extract of $H$. pogonocalyx exhibited free radical scavenging activities (Jiang et al. 2006). Therefore, the objective of this research was to develop a simple and highly efficient regeneration protocol using leaf explants and examine the antioxidant activities of the regenerated plants. The compounds from regenerated plants of $H$. pogonocalyx were also isolated, and their structures and activities were evaluated.

\section{Methods}

Plant material

Hygrophila pogonocalyx Hayata (600 g) was collected from the Highlands Experiment Farm, National Taiwan University, Taiwan and identified by Mr. Chi-Luan Wen, Seed Improvement and Propagation Station, Council of Agriculture, Taiwan. A voucher specimen (M-380) was deposited at the Graduate Institute of Pharmacognosy (Taipei Medical University, Taipei, Taiwan).

\section{Shoot proliferation and plant regeneration}

For shoot organogenesis, young leaves were used as explants and cultured on Murashige and Skoog (Murashige and Skoog 1962) basal medium supplemented with BA, NAA, IAA, or $2 \mathrm{iP}$ at different concentrations, as shown in Table 1 . The media were supplemented with $3 \%(\mathrm{w} / \mathrm{v}) \mathrm{su}-$ crose and solidified with $0.7 \%(\mathrm{w} / \mathrm{v})$ agar, and the $\mathrm{pH}$ was adjusted to 5.7. The adventitious buds rooted and regenerated into plantlets when cultured on MS medium without plant regulators. For the mass production of plantlet, six to eight node explants cut from a regenerated plantlet were cultured in sterile vessels with $100 \mathrm{ml}$ of liquid MS medium supplemented with $3 \%(\mathrm{w} / \mathrm{v})$ sucrose. The rooted plantlets were transplanted to a potting mixture $(1: 1$, peat moss: vermiculite) with garden soil. The potted plants were acclimatized for 4 weeks and then transferred to the field.

\section{Extract preparation}

The aerial parts of plants were harvested monthly, frozen at $-80^{\circ} \mathrm{C}$ for $24 \mathrm{~h}$, and lyophilized for $48 \mathrm{~h}$. All lyophilized samples were stored at room temperature.
Table 1 Effect of plant growth regulators on callus induction and shoot regeneration of leaf explants of Hygrophila pogonocalyx Hayata

\begin{tabular}{lccc}
\hline $\begin{array}{l}\text { Plant growth } \\
\text { regulators (mg/l) }\end{array}$ & $\begin{array}{c}\text { 4-week- } \\
\text { culture Callus } \\
\text { induction (\%) }\end{array}$ & \multicolumn{2}{c}{ 8-week culture } \\
\cline { 3 - 4 } & & $\begin{array}{c}\text { Shoot } \\
\text { no./explant }\end{array}$ & $\begin{array}{c}\text { Mean stem } \\
\text { length (cm) }\end{array}$ \\
\hline BA (0.1) + NAA (0.1) & 100 & $6.2 \pm 0.8^{\mathrm{d} *}$ & $1.8 \pm 0.2^{\mathrm{a}}$ \\
$\mathrm{BA}(0.5)+\mathrm{NAA}(0.1)$ & 100 & $12.2 \pm 1.9^{\mathrm{b}}$ & $0.8 \pm 0.1^{\mathrm{d}}$ \\
$\mathrm{BA}(1.0)+\mathrm{NAA}(0.1)$ & 100 & $3.8 \pm 1.3^{\mathrm{e}}$ & $0.7 \pm 0.1^{\mathrm{d}}$ \\
$\mathrm{BA}(0.1)+$ IAA (0.1) & 100 & $6.6 \pm 1.1^{\mathrm{d}}$ & $1.4 \pm 0.2^{\mathrm{b}}$ \\
$\mathrm{BA}(0.5)+$ IAA (0.1) & 100 & $22.8 \pm 1.9^{\mathrm{a}}$ & $1.0 \pm 0.1^{\mathrm{c}}$ \\
$\mathrm{BA}(1.0)+$ IAA (0.1) & 100 & $9.2 \pm 1.3^{\mathrm{c}}$ & $0.8 \pm 0.1^{\mathrm{d}}$ \\
$\mathrm{BA}(0.1)+$ IAA (0.1) + 2iP (1) & 100 & $7.2 \pm 0.8^{\mathrm{d}}$ & $1.7 \pm 0.2^{\mathrm{a}}$ \\
$\mathrm{BA}(0.5)+$ IAA (0.1) + 2iP (1) & 100 & $11.4 \pm 1.1^{\mathrm{b}}$ & $1.0 \pm 0.2^{\mathrm{c}}$ \\
$\mathrm{BA}(1.0)+$ IAA (0.1) + 2iP (1) & 100 & $9.0 \pm 0.7^{\mathrm{c}}$ & $0.7 \pm 0.1^{\mathrm{d}}$
\end{tabular}

*: In a single column, means with the same letter are not significantly different according to Duncan's multiple range tests at the 0.05 level.

\section{General experimental procedures}

Column chromatography was performed using Diaion HP 20P (100-200 mesh, Mitsubishi Chemical Industries, Tokyo, Japan), Sephadex LH-20 (100 $\mu \mathrm{m}$; Pharmacia Fine Chemicals, Piscataway, NJ), MCI gel CHP 20P (Supelco, Bellefonte, PA, USA), and octadecyl silane (ODS) columns (Merck, Darmstadt, Germany). TLC was performed on pre-coated Si gel 60 F254 plates (Merck). The ${ }^{1} \mathrm{H}$ and ${ }^{13} \mathrm{C}$ NMR spectra were recorded on an Avance DRX 500 instrument (Bruker Madison, WI). Electrospray ionization-mass spectrometry spectra were obtained on a VG platform electrospray mass spectrometer (VG Analytical, Ipswich, UK).

\section{Extraction and isolation}

The leaves of the regenerated $H$. pogonocalyx (3 kg) were macerated with $95 \% \mathrm{EtOH}$ at room temperature for 5 days, then filtered to give the residue and filtrate. The residue was treated in a similar manner as above three times. The combined filtrates were concentrated under reduced pressure to give the EtOH extract (186 g), which was divided into fractions soluble in $n$-hexane, ethyl acetate (EtOAc) and $\mathrm{H}_{2} \mathrm{O}$ by liquid-liquid partitioning. The EtOAc extract ( $30 \mathrm{~g}$ ) was re-suspended in $\mathrm{H}_{2} \mathrm{O}$, subjected to chromatography on a Diaion HP-20 column, eluted with $\mathrm{MeOH}-\mathrm{H}_{2} \mathrm{O}(0 \%, 20 \%, 40 \%, 60 \%$, and $100 \%)$ and analyzed by thin layer chromatography to obtain seven respective fractions (E-1-7). Fractions E-3 and E-4 were passed through a Sephadex $\mathrm{LH}-20$ column (95\% EtOH) to obtain 13 (E-3-1-13) and 11 (E-4-1-11) subfractions, respectively. Re-crystallization of fraction E-3-11 (20 mg) with $\mathrm{MeOH}$ yielded compound (1) (12 mg). Fraction E-4-3 (130 mg) was separated by semi-preparative HPLC (Biosil 5 ODS-W column, $10 \times 250 \mathrm{~mm}$; solvent system: $50 \%$ $\mathrm{MeOH}$; flow rate: $3.0 \mathrm{ml} / \mathrm{min}$; detector: $254 \mathrm{~nm}$ ) to give 
compounds (2) (15 mg) and (3) (16 mg). Fraction E-4-5 (45 mg) was separated by semi-preparative HPLC (solvent system: $20-100 \% \mathrm{MeOH}$ in $60 \mathrm{~min}$ ) to obtain compounds (4) and (5) (6 mg). Fraction E-4-6 (40 mg) was separated by semi-preparative HPLC (solvent system: 25\% acetonitrile and $35 \% \mathrm{MeOH}$, respectively) to give compound (6) (4 mg). Compounds (7) (29 mg) and (8) (5 mg) were obtained from fraction E-4-7 (120 mg) by semi-preparative HPLC (solvent system: 25\% acetonitrile and 40\% $\mathrm{MeOH}$ ). Compound (9) (5 mg) was obtained from fraction E-4-9 (43 mg) by semi-preparative HPLC (solvent system: 30\% $\mathrm{MeOH})$. Fraction E-6 (100 mg) was subjected to an ODS column and eluted with $20-100 \% \mathrm{MeOH}$ to obtain compound (10) (7 mg).

The $n$-butanol extract (35 g) was eluted on a Sephadex LH-20 column with $100 \% \mathrm{MeOH}$ to obtain nine fractions (B-1-9). After monitoring by HPLC evaluation, B-6 was subjected to MCI gel CHP 20P column chromatography. Fraction B-6 was eluted with a stepwise gradient of aqueous methanol $\left(\mathrm{H}_{2} \mathrm{O}\right.$ to $\left.100 \% \mathrm{MeOH}\right)$, yielding 14 fractions (B-6-1-14). A precipitate was evident in the B-6-5 fraction (85 mg). Re-crystallizing the precipitate with $\mathrm{MeOH}$ and $\mathrm{H}_{2} \mathrm{O}$ yielded pure compound (11) (21 mg). Compound (12) (10 mg) was obtained from B-6-14 (120 mg). A precipitate from B-9 (105 mg) was re-crystallized with $\mathrm{MeOH}$ and $\mathrm{H}_{2} \mathrm{O}$ to yield pure compound (13) (11 mg). The spectral data and physical constants for isolated compounds were included in Supporting information (Additional file 1).

\section{Antioxidant activities}

\section{1, 1-Diphenyl-2-picrylhydrazyl (DPPH) radical scavenging activity}

DPPH radical scavenging effect was measured according to the method of Hou et al. (Hou et al. 2003). Each tested sample was mixed with $160 \mu \mathrm{M}$ DPPH in an $\mathrm{MeOH}$ solution. After a 20-min incubation at room temperature in the dark, the absorbance was read at $517 \mathrm{~nm}$. The inhibitory percentage of DPPH was calculated according to the following equation:

$$
\begin{aligned}
& \text { DPPH radical scavenging activity }(\%) \\
& \quad=[(\mathrm{A} 0-\mathrm{A} 1) / \mathrm{A} 0] \times 100 \% .
\end{aligned}
$$

A0 was the absorbance of the control (blank, without extract), and A1 was the absorbance in the presence of the tested samples.

\section{Ferrous ion chelating activity}

The ferrous ion chelating activity was determined by the $\mathrm{Fe}^{2+}$-ferrozine test system using the method of ErdoganOrhan et al. (Erdogan-Orhan et al. 2010). In brief, the test samples were incubated with $2 \mathrm{mM} \mathrm{FeCl}_{2}$ solution. The reaction was initiated by adding ferrozine solution to the mixture and incubating the mixture for $10 \mathrm{~min}$ at room temperature. The absorbance of the reaction mixture was measured at $562 \mathrm{~nm}$. The ratio of inhibition of ferrozine- $\mathrm{Fe}^{2+}$ complex formation was calculated as follows:

$$
\% \text { Inhibition }=[(\mathrm{A} 0-\mathrm{A} 1) / \mathrm{A} 0] \times 100 \%
$$

A0 was the absorbance of the control (blank, without extract), and A1 was the absorbance in the presence of the tested samples.

\section{Total phenol}

The amount of total phenolics in the extracts was determined according to the method of Hou et al. (Hou et al. 2003). The test sample solution was mixed with the FolinCiocalteu reagent, $20 \%$ sodium carbonate $\left(\mathrm{Na}_{2} \mathrm{CO}_{3}\right)$ solution, and water. After incubation for $25 \mathrm{~min}$ at room temperature, the reaction mixture was centrifuged at $5000 \mathrm{rpm}$ for $10 \mathrm{~min}$. The absorbance of the supernatant was measured at $730 \mathrm{~nm}$ by using a spectrophotometer. The amount of total phenolics was expressed as gallic acid equivalents in milligrams per gram dry plant extract.

\section{Anti-melanogenic activity}

\section{Cell viability of human epidermal melanocytes (HEMn cells)}

Cells $\left(1 \times 10^{5}\right)$ were added to individual wells of a 24-well plate. After incubation for $24 \mathrm{~h}$, a test sample $(100 \mu \mathrm{M})$ was added to each well and incubated for another $24 \mathrm{~h}$. Cell viability was then determined at $450 \mathrm{~nm}$ on a $\mu$ Quant microplate reader (Bio-Tek Instruments, Inc.) by using the WST-8 cell proliferation assay.

\section{Cellular tyrosinase activity in HEMn cells}

Cellular tyrosinase activity was measured using a previously described method (Lee et al. 2006). After treatment with individual compounds $(100 \mu \mathrm{M})$ for $24 \mathrm{~h}$, the cells were washed with potassium phosphate-buffered saline (PBS) and lysed with PBS ( $\mathrm{pH}$ 6.8) containing 1\% Triton X-100. Protein content was determined using a commercial protein assay kit (Bio-Rad, Hercules, CA). After quantifying protein levels, $40 \mu \mathrm{g}$ of protein, $2.5 \mathrm{mM}$ L-DOPA, and 0.1 M PBS ( $\mathrm{pH}$ 6.8) was added to each well (the same protein content) of a 96-well plate. After incubation at $37^{\circ} \mathrm{C}$ for $1 \mathrm{~h}$, the absorbance was measured at $475 \mathrm{~nm}$ by using an enzyme-linked immunosorbent assay reader.

\section{Neurocytoprotective activity \\ PC12 cell culture}

PC12 cells $\left(2 \times 10^{5}\right)$ were grown in RPMI 1640 medium supplemented with horse serum (10\%) and fetal bovine serum $(5 \%)$ at $37^{\circ} \mathrm{C}$ in a humidified $5 \% \mathrm{CO}_{2}$ atmosphere (Lin et al. 2010). Cells were seeded in the plate and cultured 
with $100 \mathrm{ng} / \mathrm{ml}$ nerve growth factor (NGF) for 5 days. 6-Hydroxydopamine (6-OHDA) was used to produce oxidative stress. PC12 cells were treated with the test samples $(100 \mu \mathrm{M})$ for $6 \mathrm{~h}$ before exposure to $175 \mu \mathrm{M}$ 6-OHDA (Lin et al. 2010).

\section{Cell viability and neurocytoprotective activity of PC12 cells}

PC12 cell growth was evaluated using the WST-8 assay (Lin et al. 2010). PC12 cells were seeded on a 96-well plate in culture medium and NGF for 5 days and then treated with the test compounds $(100 \mu \mathrm{M})$ for $24 \mathrm{~h}$. WST-8 reagent was added, and cells were incubated for $4 \mathrm{~h}$, after which their viability was analyzed using a $\mu$ Quant microplate reader (Bio-Tek Instruments, Winooski, VT, USA) at $450 \mathrm{~nm}$. The absorbance values of the experimental cultures were used to indicate the levels of cell viability. Neurocytoprotective activity was evaluated the cell viability that the differentiation PC12 pre-treated with the test compounds $(100 \mu \mathrm{M})$ for $6 \mathrm{~h}$ before exposure to 6-OHDA.

\section{Statistical analysis}

Experiments were replicated three times for each analysis, and data were analyzed by analysis of variance
(ANOVA) using Statistical Analysis system (SAS) and tested for significance by Duncan's multiple range test (Duncan 1955) at the 5\% level.

\section{Results}

Effect of plant growth regulators on shoot organogenesis from leaf explants

Friable callus developed from leaf explants, after which adventitious buds were visible on the surface of the callus (Figure 1). The callus induction rate was $100 \%$ when leaf explants were cultured on nine test media. Table 1 shows the effect of different concentrations of plant growth regulators on the average number of shoots produced per explant and average shoot length. The MS basal medium supplemented with $0.5 \mathrm{mg} / \mathrm{l} \mathrm{BA}$ and $0.1 \mathrm{mg} / \mathrm{l}$ IAA provided the best multiplication rate, with an average value of $22.8 \pm 1.9$ buds per explant after 8 weeks of culture. The average shoot length was higher when the medium contained a low BA concentration $(0.1 \mathrm{mg} / \mathrm{l})$ in combination with IAA, NAA, or $2 \mathrm{iP}$.

\section{Plant regeneration}

The adventitious buds rooted and regenerated into plantlets when cultured on MS medium without plant
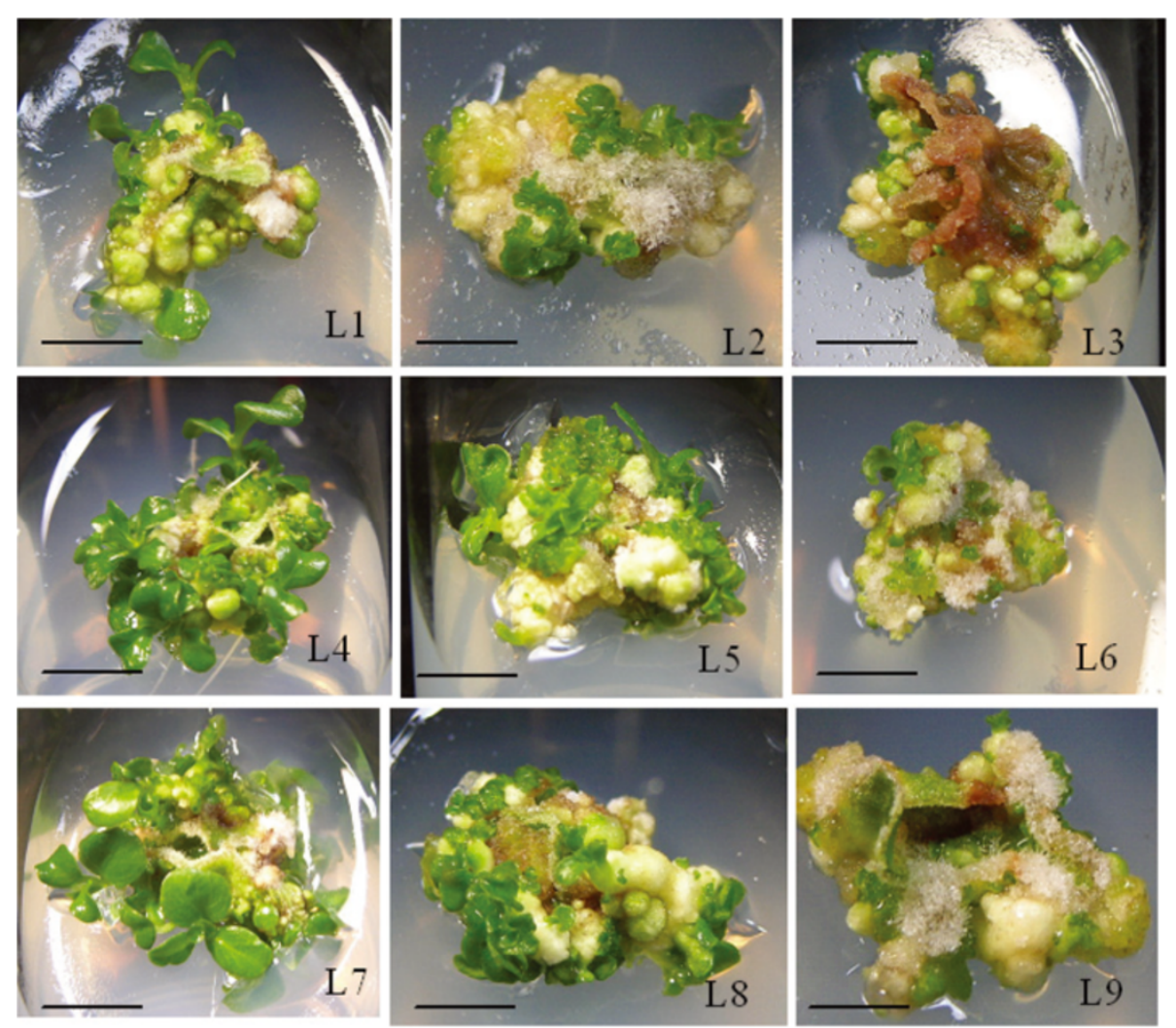

Figure 1 Callus and adventitious shoot regeneration of leaf explants of Hygrophila pogonocalyx cultured with different concentrations (mg/l) of plant growth regulators. L1: BA (0.1) + NAA (0.1); L2: BA (0.5) + NAA (0.1); L3: BA (1) + NAA (0.1); L4: BA (0.1) + IAA (0.1); L5: BA (0.5) + IAA (0.1); L6: BA (1) + IAA (0.1); L7: BA (0.1) + IAA (0.1) + 2iP (1) ; L8: BA (0.5) + IAA (0.1) + 2iP(1); L9: BA (1) + IAA (0.1) + 2iP (1) (bar $=1 \mathrm{~cm})$. 
regulators after 1 week. For the mass production of plantlets, six to eight node explants were cultured in sterile vessels with liquid MS medium. After 6 weeks of culture, the rooted plantlets (Figure 2) were transplanted to a potting mixture (1:1, peat moss: vermiculite) with garden soil. The potted plants were acclimatized for 4 weeks and then transferred to the field. In 1 year, using the above protocol, 37,600 plants could be produced from a single leaf explant.

\section{Antioxidant activities}

The antioxidant activities of tissues of $H$. pogonocalyx collected in different seasons are presented in Table 2. Tissues harvested in June exhibited the highest DPPH radical scavenging activity (3175.4 $\pm 17.8 \mathrm{mg} \mathrm{AA} / 100 \mathrm{~g} \mathrm{DW})$ and total phenol content $(127.1 \pm 0.0 \mathrm{mg}$ GA/100 g DW). The ferrous ion chelating activity of tissues collected in May was substantial $(57.0 \pm 13.3 \mu \mathrm{mol}$ EDTA/g DW).

\section{Purification and identification of constituents of tissues produced by indirect shoot organogenesis from leaf explants of $H$. pogonocalyx}

In the present study, the leaves produced by indirect shoot organogenesis from leaf explants of $H$. pogonocalyx were extracted with $95 \% \mathrm{EtOH}$, and then phytochemical investigations were conducted. The extract was re-suspended in $\mathrm{H}_{2} \mathrm{O}$ and partitioned with $n$-hexane, ethyl acetate, and $n$-butanol sequentially. HPLC-directed isolation (of the EtOAc and $n$-butanol fractions) was performed after subjecting these fractions to Diaion HP20, Sephadex LH-20, and MCI CHP-20P column chromatography and semi-HPLC purification. From the EtOAc and $n$-butanol fractions, we obtained 10 ((1)(10)) and 3 compounds ((11)-(13)), respectively. Structural identification of these compounds was achieved by

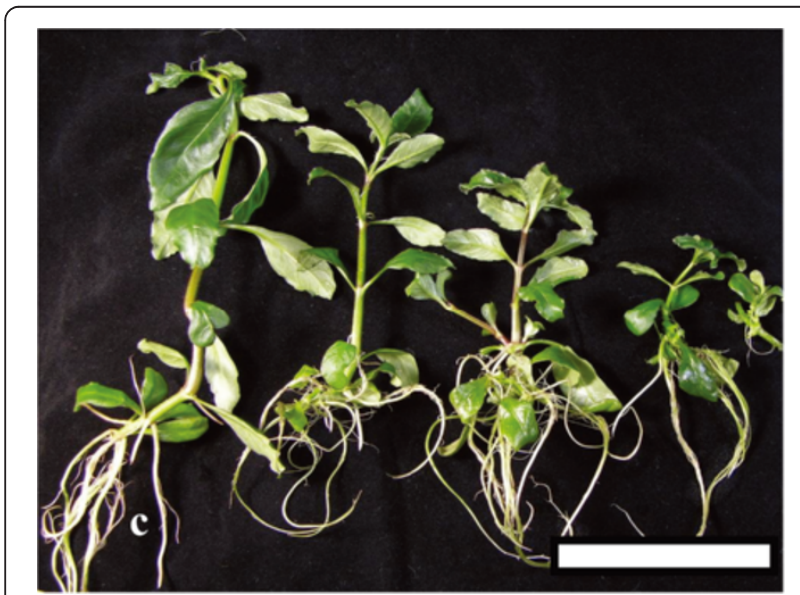

Figure 2 The adventitious buds rooted and regenerated into plantlets when cultured on MS medium without plant regulators. $\mathrm{Bar}=7.5 \mathrm{~cm}$.
Table 2 The effect of season on the antioxidant activities of the ethanol extracts of Hygrophila pogonocalyx Hayata

\begin{tabular}{|c|c|c|c|}
\hline & $\begin{array}{l}\text { Ferrous ion } \\
\text { chelating } \\
\text { activity }(\%)\end{array}$ & $\begin{array}{l}\text { DPPH radical } \\
\text { scavenging } \\
\text { activity }\end{array}$ & $\begin{array}{c}\text { Total } \\
\text { phenol }\end{array}$ \\
\hline & $\mu \mathrm{mol}$ EDTA/g DW* & $\mathrm{AEAC}^{* *}$ & $\mathrm{mg} \mathrm{GA} / 100 \mathrm{~g} \mathrm{DW}^{\#}$ \\
\hline March & $8.3 \pm 0.0^{c, \# \#}$ & $2914.0 \pm 25.0 \mathrm{bc}$ & $117.5 \pm 0.0^{c}$ \\
\hline April & $7.4 \pm 0.0^{c}$ & $2495.5 \pm 7.8^{d}$ & $91.6 \pm 0.0^{f}$ \\
\hline May & $57.0 \pm 13.3^{a}$ & $2727.4 \pm 9.2^{c d}$ & $98.6 \pm 0.0^{e}$ \\
\hline June & $17.5 \pm 1.2^{b}$ & $3175.4 \pm 17.8^{a}$ & $127.1 \pm 0.0^{a}$ \\
\hline September & $4.1 \pm 0.2^{c}$ & $2979.6 \pm 356.8^{a b}$ & $122.3 \pm 0.0^{b}$ \\
\hline October & $4.4 \pm 0.1^{c}$ & $2542.2 \pm 43.3^{d}$ & $92.3 \pm 0.0^{f}$ \\
\hline November & $3.3 \pm 0.2^{c}$ & $2619.8 \pm 24.4^{d}$ & $106.0 \pm 0.0^{d}$ \\
\hline December & $2.8 \pm 0.1^{c}$ & $2896.9 \pm 36.6^{b c}$ & $118.8 \pm 0.1^{b c}$ \\
\hline
\end{tabular}

*: $\mu \mathrm{mol}$ EDTA/g DW: micromole EDTA equivalents per gram of plant dry weight.

**: Ascorbic acid equivalent antioxidant activity: milligram of ascorbic acid equivalents per $100 \mathrm{~g}$ of plant dry weight (mg AA/100 g DW).

\#: mg GA/100 g DW: milligrams of gallic acid equivalents per $100 \mathrm{~g}$ of plant dry weight.

\#\#: In a single column, means with the same letter are not significantly different according to Duncan's multiple range tests at the 0.05 level.

comparison of their physical data $\left({ }^{1} \mathrm{H}\right.$ and ${ }^{13} \mathrm{C}$ NMR, MS) spectral data with those reported in literature. They belong to flavones (luteolin 7-O- $\beta$-D-glucuronide (1) (Lee et al. 2002) and luteolin 7-O- $\beta$-D-glucopyranoside (11) (Shi et al. 2008)), flavonols (myricetin (9) (Ibrahim et al. 2001), quercetin (10) (Min et al. 2010), rutin (12) (Zou et al. 2010), and isoquercitrin (13)), phenylethanoid glycosides ( $\beta$-ethoxylacteoside (6) (Jun et al. 2003), acteoside (7) (Henry et al. 1987), and isoacteoside (8) (Kim et al. 2001)), alkylated glycosides (3-O-[ $\beta$-D-apiofuranosyl- $(1 \rightarrow 6)-\beta$-D-glucopyranosyl] oct-1-en-3-ol $\quad(2)$ (Zou et al. 2008) and 3-O-[ $\alpha$-L-xylopyranosyl- $(1 \rightarrow 6)-\beta$ D-glucopyranosyl]oct-1-en-3-ol (3) (Yamamura et al. 1998), and steroids ( $\beta$-sitosterol (4) and stigmasterol (5) (Hisash et al. 1990)). The structures of these compounds are shown in Figure 3. These compounds represent substances isolated from leaves produced by indirect shoot organogenesis from leaf explants of $H$. pogonocalyx for the first time. Excluding the steroids (4) and (5), each of the isolated constituents was examined separately at a relatively high concentration $(100 \mu \mathrm{M})$ for antimelanogenic and neurocytoprotective activities.

Cytotoxicity and anti-melanogenic activity of isolated constituents from $H$. pogonocalyx in HEMn cells

The isolated constituents from $H$. pogonocalyx were further evaluated for anti-melanogenic activity. Using the MTT assay, cells were exposed to 11 test samples, and all cells exhibited greater than $85 \%$ viability (Figure $4 \mathrm{~A}$ ) after a 24-h treatment, demonstrating that the isolated compounds exhibited no or little cytotoxicity in HEMn cells. Afterward, the 11 test compounds were then examined for cellular anti-tyrosinase activity. Acteoside (7) 

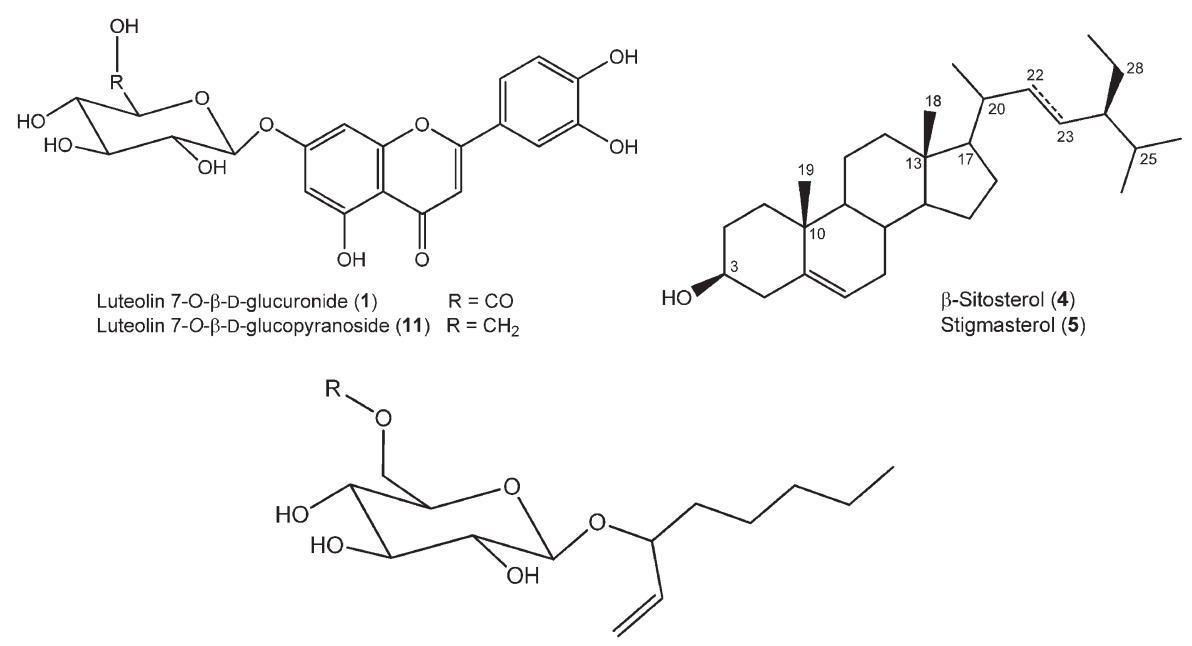

3-O-[ $\beta$-D-Apiofuranosyl-( $1 \rightarrow 6)-\beta$-D-glucopyranosyl]oct-1-en-3-ol $(\mathbf{2}) \quad \mathrm{R}=$ apiose 3-O-[ $\alpha$-L-Xylopyranosyl- $(1 \rightarrow 6)-\beta$-D-glucopyranosyl]oct-1-en-3-ol $(3) \quad R=$ xylose

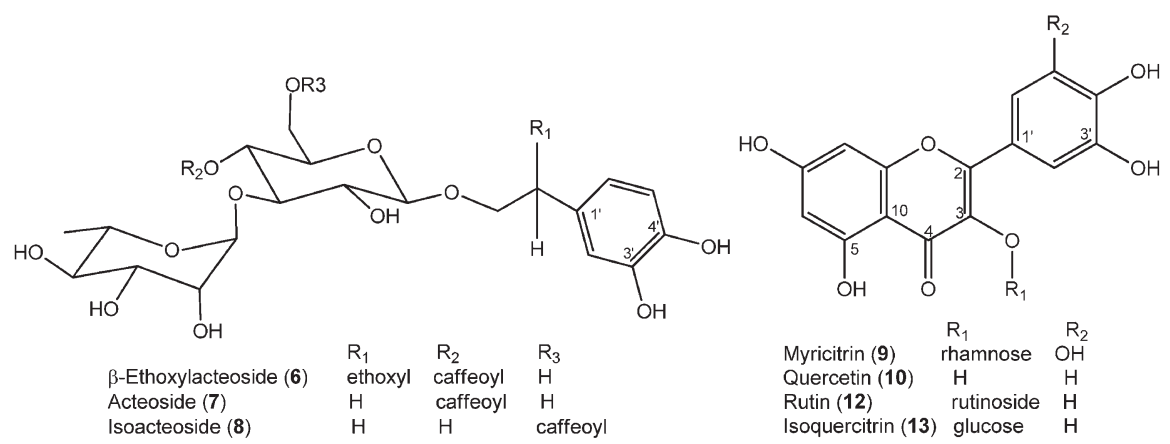

Figure 3 Structures of the isolated compounds from leaf explants of $H$. pogonocalyx.

exhibited greater anti-tyrosinase activity than the positive control arbutin, and luteolin 7-O- $\beta$-D-glucopyranoside (1), isoacteoside (8), and rutin (12) displayed antityrosinase activity (Figure 4B).

\section{Cytotoxicity and neurocytoprotective activity of isolated constituents from $\mathrm{H}$. pogonocalyx in NGF-differentiated PC12 cells}

The NGF-differentiated PC12 cells were used as a model to assess neurocytoprotective activity in the present study. In our previous study, we found that when NGF-differentiated PC12 cells were treated with $175 \mu \mathrm{M}$ 6-OHDA for $24 \mathrm{~h}$, cell viability decreased to $50.0 \pm 4.6 \%$ compared with that of the untreated cells (Lin et al. 2009). Therefore, we used $175 \mu \mathrm{M}$ 6-OHDA to induce cytotoxicity in the subsequent experiment.

Using the WST-8 assay to evaluate cytotoxicity, PC12 cells were exposed to the test samples, and all cells exhibited greater than $90 \%$ viability following 24 h of treatment, which indicated that the isolated compounds did not induce PC12 cell cytotoxicity (Figure 5A). The NGFdifferentiated PC12 cells were incubated with the test compounds $(100 \mu \mathrm{M})$ prior to 6-OHDA exposure, and luteolin 7-O- $\beta$-D-glucopyranoside (11) exhibited potent neurocytoprotective activity. Luteolin 7-O- $\beta$-D-glucuronide (1), myricetin (9), and rutin (12) exhibited slightly protective activities (Figure 5B).

\section{Discussion}

$H$. pogonocalyx is a rare endemic species in Taiwan. The extract of $H$. pogonocalyx exhibited the free radical scavenging activities in our previous study (Jiang et al. 2006). Plant tissue culture is often used for plant propagation. Different techniques in plant tissue culture may offer the ability to generate exact copies of plants. Using this technique, the proliferation of a large number of specific plant tissues or cells can be controlled in an external environment to create a regeneration system to produce a large population of seedlings and then achieve the conservation of the sources of plant species. In the present report, we develop a simple and highly efficient regeneration protocol using leaf explants. The percentage of callus induction in leaf explant of $H$. pogonocalyx was $100 \%$ on MS medium supplemented with all tested plant growth regulators and combinations (Table 1). Explants cultured on medium containing $0.5 \mathrm{mg} / \mathrm{l} \mathrm{BA}$ combined 

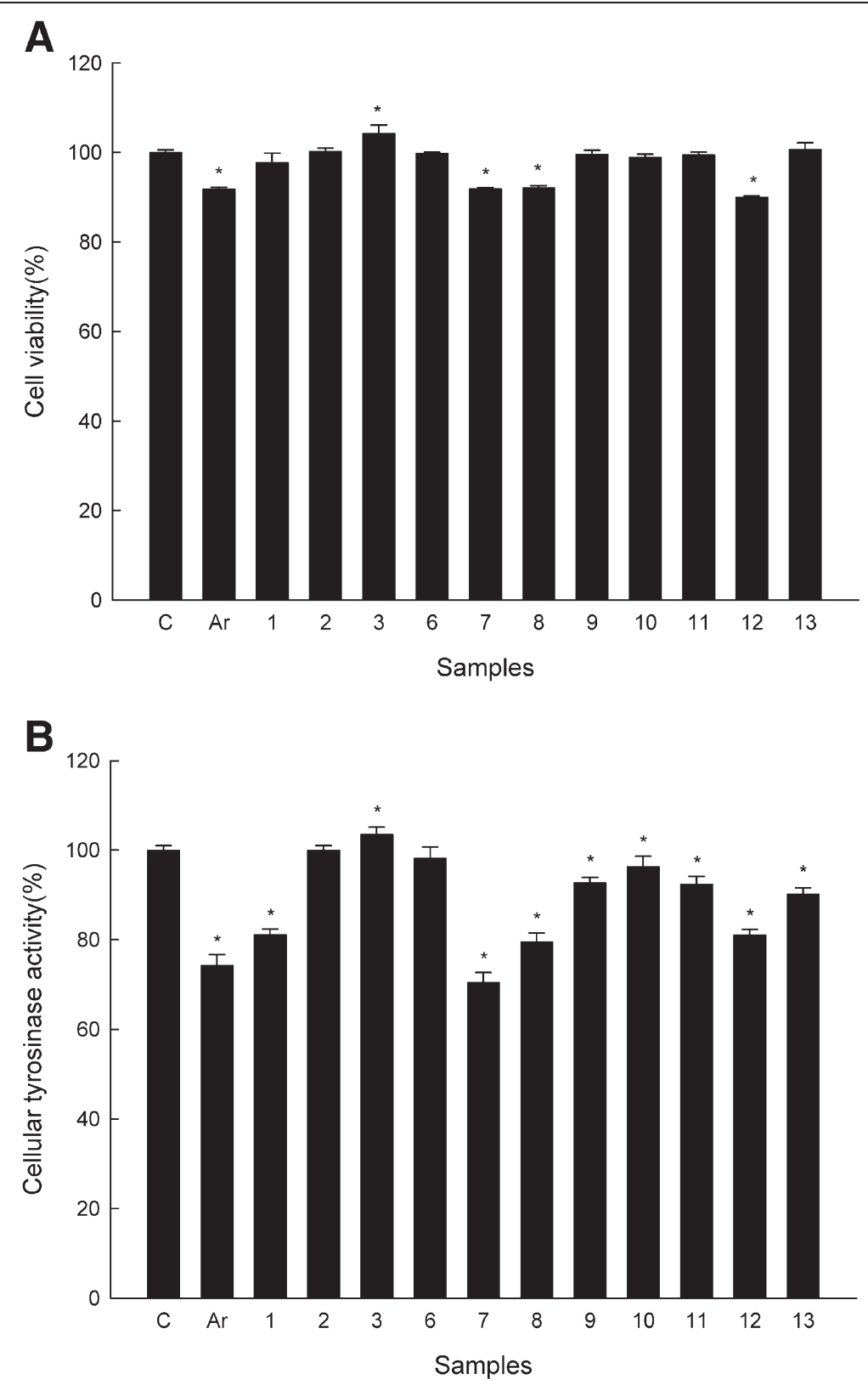

Figure 4 Cytotoxicity and cellular anti-tyrosinase activity of the isolated constituents of $H$. pogonocalyx in human epidermal melanocytes (HEMn cells). HEMn cells $\left(1 \times 10^{5}\right)$ were treated with the positive control arbutin (Ar) and the isolated compounds $(100 \mu \mathrm{M})$ for $24 \mathrm{~h}$. Afterward, (A) the supernatant was removed and incubated with WST-8 cell counting reagent for $4 \mathrm{~h}$ at $37^{\circ} \mathrm{C}$. The absorbance was measured using a microplate reader at $450 \mathrm{~nm}$. (B) The lysates (equal amount of proteins) were incubated with L-dopa at a final concentration $2.5 \mathrm{mM}$ for $1 \mathrm{~h}$ at $37^{\circ} \mathrm{C}$. Each determination was made in triplicate, and the data shown represent means \pm SD. *P-value $<0.05$ when compared with control.

with NAA, IAA, or 2iP exhibited effective shoot regeneration from callus. The highest number of shoots produced per explant was $22.8 \pm 1.9$. The longest shoots were produced from leaf explants $(1.8 \pm 0.2 \mathrm{~cm})$ cultured on medium containing $0.1 \mathrm{mg} / \mathrm{l} \mathrm{BA}$ supplemented with NAA, IAA, or $2 \mathrm{iP}$. In the present investigation, BA played an important role as a plant growth regulator, and it had a significant effect on the average number of shoots per explant. Similar findings were obtained for Justicia gendarussa using nodal explants, as the maximal shoot induction was obtained on MS medium supplemented with 17.7 $\mu$ M BA (Balaraju et al. 2008, Sudha and Seeni 1994), and for the micropropagation of $V$. agnus-castus from nodal and meristem explants, the highest shoot regeneration was produced using MS medium supplemented with $2 \mathrm{mg} / \mathrm{l} \mathrm{BA}$ (Balaraju et al. 2008; Sudha and Seeni 1994).

Rooting occurred with regenerated shoots cultured on MS medium without plant growth regulators. However, 

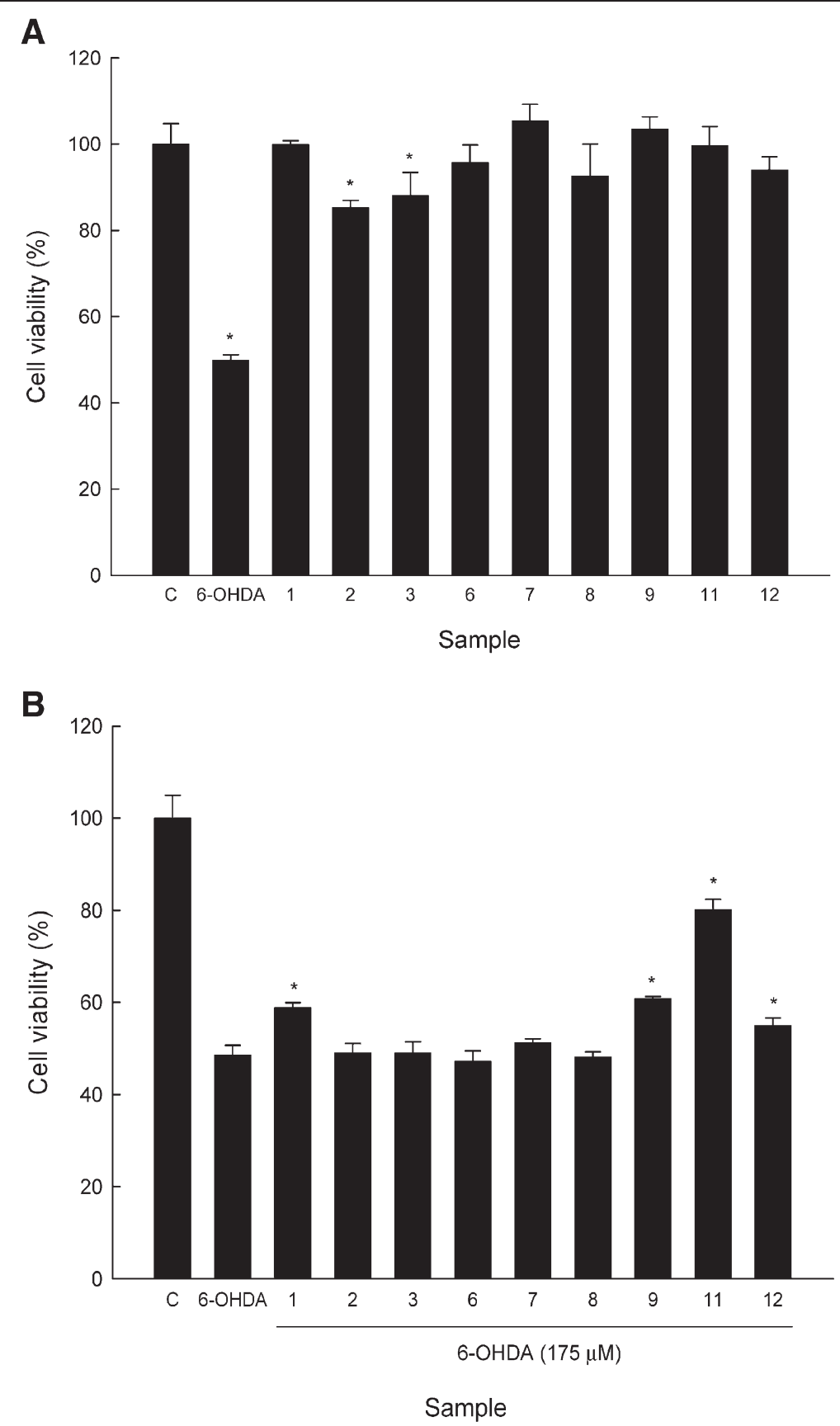

Figure 5 Cytotoxicity and neurocytoprotective activity of the isolated constituents of $H$. pogonocalyx in 6-OHDA-induced NGF-differentiated PC12 cells. (A) NGF-differentiated PC12 cells $\left(2 \times 10^{5}\right)$ were treated with 6-OHDA (175 $\left.\mu \mathrm{M}\right)$ and tested samples $(100 \mu \mathrm{M})$ for $24 \mathrm{~h}$. (B) The NGF-differentiated PC12 cells $\left(2 \times 10^{5}\right)$ were treated with the tested constituents $(100 \mu \mathrm{M})$ for $6 \mathrm{~h}$ and then were treated with 6-OHDA $(175 \mu \mathrm{M})$ for $24 \mathrm{~h}$. The cell-protective activity was calculated as follows: $\left(\mathrm{OD}_{450}\right.$ of the sample/OD 450 of $\left.6-\mathrm{OHDA}\right) \times 100$. Each determination was made in triplicate, and the data shown represent means \pm SD. *P-value $<0.05$ when compared with control.

$9.8 \mu \mathrm{M}$ IBA mostly effectively induced rooting (73\%) in J. gendarussa (Balaraju et al. 2008, Sudha and Seeni 1994). Balaraju et al. also reported that medium supplemented with IBA enhanced the in vitro rooting of $V$. agnus-castus (Balaraju et al. 2008; Sudha and Seeni 1994). In this study, root initiation occurred immediately after the transfer of cultures to the root induction medium without regulators. An efficient rooting protocol to obtain whole plants was established. After 6 weeks of culture, the rooted plantlets were transplanted to a potting mixture, and potted plants were acclimatized for 4 weeks before being transferred to the field. The ex 
vitro survival rate of plantlets was $100 \%$. In 1 year, by using this efficient protocol, 37,600 plants could be produced from a single leaf explant.

Using this method, we can obtain the source of raw materials. Thirteen compounds were isolated from the leaves of micropropagated plants of $H$. pogonocalyx. This is the first report on the chemical investigation of micropropagated $H$. pogonocalyx produced from leaf explants. Most of the popular de-pigmenting agents in current use are toward non-toxic natural products. Reactive oxygen species (ROS) and free radical-mediated reactions are involved in many degenerative and pathological processes, such as neurodegenerative diseases (Lee and Wei 2012). Therefore, these isolated compounds were evaluated for anti-melanogenic activity in human melanocytes and neurocytoprotective activity in $\mathrm{PC} 12$ cells in the present study. Among them, acteoside (7) exhibited the greatest anti-tyrosinase activity, and luteolin 7-O- $\beta-\mathrm{D}-$ glucopyranoside (11) exhibited the greatest neurocytoprotective activity. Acteoside is a type of phenylethanoid glycoside found in bitter tea and many medicinal plants, and diverse biological activities ( $\mathrm{He}$ et al. 2011) including chemopreventive (Hwang et al. 2011), antiallergic (Yamada et al. 2010), and hepatoprotective (Zhao et al. 2009) activities have been reported for this compound. Acteoside was reported to protect cells from oxidative stress and free radical-mediated impairment of endothelial function (Chiou et al. 2004). It was also reported to decrease tyrosinase activity and melanin biosynthesis in B16F10 melanoma cells (Son et al. 2011). However, the anti-tyrosinase activity of acteoside in normal human epidermal melanocytes was confirmed in this study for the first time. The isolated compound, luteolin 7-O- $\beta-\mathrm{D}-$ glucopyranoside (11), showed the protective effect against 6-OHDA-induced PC12 cells. The result was similar to our previous data (Lin et al. 2009, 2012). Rutin (12) exhibited protective effect against spatial memory impairment induced by trimethyltin in rats and toxicantinduced hippocampal injury (Koda et al. 2008, 2009). In this study, rutin (12) showed the neurocytoprotective effect in 6-OHDA-induced NGF-differentiated PC12 cells. These two isolated compounds could be the neurocytoprotective indicators in this plant. Myricetin (9) exhibited antiallergic (Shimosaki et al. 2011), antipsychoticlike (Pereira et al. 2011), and anxiolytic (Fernandez et al. 2009) effects. There is no report of neuroprotective activity for myricetin.

\section{Conclusion}

In summary, to our knowledge, this is the first report to develop a method of indirect shoot organogenesis from leaf explants of $H$. pogonocalyx. The method could be developed to supply enough quantity of plant materials for the first chemical and pharmacological investigation.
These pharmacological results may promote to development for whitening agents and treatment for neurodegenerative diseases in the future.

\section{Additional file}

\section{Additional file 1: Supporting Information.}

\section{Abbreviations}

BA: 6-benzyladenine; 2iP: 6-( $\gamma$, $\gamma$-dimethylallylamino)-purine; IAA: Indole-3acetic acid; IBA: Indole-3-butyric acid; NAA: a-naphthalene acetic acid.

\section{Competing interests}

The authors declare that they have no competing interests.

\section{Authors' contributions}

$\mathrm{CWH}, \mathrm{RDL}, \mathrm{THL}, \mathrm{CHL}, \mathrm{CLW}, \mathrm{YTT}$, and $\mathrm{MHL}$ participated in the research and drafted the manuscript. All authors read and approved the final manuscript.

\section{Acknowledgements}

The authors express thanks for the financial support provided by a grant from the National Science Council, Republic of China (NSC 98-2320-B-038 $016-\mathrm{MY} 3)$

\section{Author details}

${ }^{1}$ Department of Bioengineering, Tatung University, Taipei 104, Taiwan. ${ }^{2}$ Department of Internal Medicine, Ho-Ping Branch, Taipei City Hospital, Taipei 100, Taiwan. ${ }^{3}$ Graduate Institute of Pharmacognosy, College of Pharmacy, Taipei Medical University, Taipei 110, Taiwan. ${ }^{4}$ Seed Improvement and Propagation Station, Council of Agriculture, Taichung 515, Taiwan. ${ }^{5}$ Center for Reproductive Medicine \& Sciences, Taipei Medical University Hospital, Taipei 110, Taiwan.

Received: 3 February 2012 Accepted: 21 November 2012 Published: 30 October 2013

\section{References}

Balaraju K, Agastian P, Preetamraj JP, Arokiyaraj S, Ignacimuthu S (2008) Micropropagation of Vitex agnus-castus, (Verbenaceae) - a valuable medicinal plant. In Vitro Cell Dev Biol Plant 44:436-441

Bibu KJ, Joy AD, Mercey KA (2010) Therapeutic effect of ethanolic extract of Hygrophila spinosa T. Anders on gentamicin-induced nephrotoxicity in rats. Indian J Exp Biol 48:911-917

Chiou WF, Lin LC, Chen CF (2004) Acteoside protects endothelial cells against free radical-induced oxidative stress. J Pharm Pharmacol 56:743-748

Erdogan-Orhan I, Sever-Yilmaz B, Altun ML, Saltan G (2010) Radical quenching activity, ferric-reducing antioxidant power, and ferrous ion-chelating capacity of 16 Ballota species and their total phenol and flavonoid contents. J Med Food 13:1537-1543

Fernandez SP, Nguyen M, Yow TT, Chu C, Johnston GA, Hanrahan JR, Chebib M (2009) The flavonoid glycosides, myricitrin, gossypin and naringin exert anxiolytic action in mice. Neurochem Res 34:1867-1875

He J, Hu XP, Zeng Y, Li Y, Wu HQ, Qiu RZ, Ma WJ, Li T, Li CY, He ZD (2011) Advanced research on acteoside for chemistry and bioactivities. J Asian Nat Prod Res 13:449-464

Henry M, Roussel JL, Andary C (1987) Verbascoside production in callus and suspension cultures of Hygrophila erecta. Phytochemistry 26:1961-1963

Hisash K, Noriko S, Akiko H, Haruo O (1990) Sterol glucosides from Prunella vulgaris. Phytochemistry 29:2351-2355

Hou WC, Lin RD, Cheng KT, Hung YT, Cho CH, Chen CH, Hwang SY, Lee MH (2003) Free radical-scavenging activity of Taiwanese native plants. Phytomedicine 10:170-175

Hsieh CF, Huang TC (1974) The Acanthaceous plants of Taiwan. Taiwania 19:19-57

Huang JC, Win CZ (1999) The propagation of Hygrophila pogonocalyx Hayata. J Nat Conserv 26:34-37

Hwang YP, Kim HG, Choi JH, Park BH, Jeong MH, Jeong TC, Jeong HG (2011) Acteoside inhibits PMA-induced matrix metalloproteinase-9 expression via CaMK/ERK- and JNK/NF-kappaB-dependent signaling. Mol Nutr Food Res 55 (Suppl 1):S103-S116 
Ibrahim I, Mahmoud MS, Marzouk AM, Moharrama MR (2001) Acylated flavonol glycosides from Eugenia jambolana leaves. Phytochemistry 58:1239-1244

Jiang CB, Chang MJ, Wem CL, Lin YP, Hsu FL, Lee MH (2006) Natural products of cosmetics: analysis of extracts of plants endemic to Taiwan for the presence of tyrosinase-inhibitory, melanin-reducing, and free radical scavenging activities. J Food Drug Anal 14:346-352

Jun W, Huang J, Long L, Huang L (2003) Phenylethanoid and aliphatic alcohol glycosides from Acanthus ilicifolius. Phytochemistry 63:491-495

Khan MR, Omoloso AD (2002) Antibacterial activity of Hygrophila stricta and Peperomia pellucida. Fitoterapia 73:251-254

Kim HJ, Woo ER, Shin CG, Hwang DJ, Park H, Lee YS (2001) HIV-1 integrase inhibitory phenylpropanoid glycosides from Clerodendron trichotomum. Arch Pharm Res 24:286-291

Koda T, Kuroda Y, Imai H (2008) Protective effect of rutin against spatial memory impairment induced by trimethyltin in rats. Nutr Res 28:629-634

Koda T, Kuroda Y, Imai H (2009) Rutin supplementation in the diet has protective effects against toxicant-induced hippocampal injury by suppression of microglial activation and pro-inflammatory cytokines: protective effect of rutin against toxicant-induced hippocampal injury. Cell Mol Neurobiol 29:523-531

Lee HC, Wei YH (2012) Mitochondria and aging. Adv Exp Med Biol 942:311-327

Lee MH, Son YK, Han YN (2002) Tissue factor inhibitory flavonoids from the fruits of Chaenomeles sinensis. Arch Pharm Res 25:842-850

Lee MH, Lin YP, Hsu FL, Zhan GR, Yen KY (2006) Bioactive constituents of Spatholobus suberectus in regulating tyrosinase-related proteins and mRNA in HEMn cells. Phytochemistry 67:1262-1270

Lin YP, Chen TY, Tseng HW, Lee MH, Chen ST (2009) Neural cell protective compounds isolated from Phoenix hanceana var. formosana. Phytochemistry 70:1173-1181

Lin CM, Lin RD, Chen ST, Lin YP, Chiu WT, Lin JW, Hsu FL, Lee MH (2010) Neurocytoprotective effects of the bioactive constituents of Pueraria thomsonii in 6-hydroxydopamine (6-OHDA)-treated nerve growth factor (NGF)-differentiated PC12 cells. Phytochemistry 71:2147-2156

Lin YP, Chen TY, Tseng HW, Lee MH, Chen ST (2012) Chemical and biological evaluation of nephrocizin in protecting nerve growth factor-differentiated PC12 cells by 6-hydroxydopamine-induced neurotoxicity. Phytochemistry. In Press

Mazumdar UK, Gupta M, Maiti S, Mukherjee D (1997) Antitumor activity of Hygrophila spinosa on Ehrlich ascites carcinoma and sarcoma-180 induced mice. Indian J Exp Biol 35:473-477

Min BS, Cuong TD, Lee JS, Shin BS, Woo MH, Hung TM (2010) Cholinesterase inhibitors from Cleistocalyx operculatus buds. Arch Pharm Res 33:1665-1670

Murashige T, Skoog F (1962) A revised medium for rapid growth and bioassays with tobacco tissue culture. Physiol Plant 15:473-497

Pal D, Samanta K (2011) CNS activities of ethanol extract of aerial parts of Hygrophila difformis in mice. Acta Pol Pharm 68:75-81

Pereira M, Siba IP, Chioca LR, Correia D, Vital MA, Pizzolatti MG, Santos AR, Andreatini R (2011) Myricitrin, a nitric oxide and protein kinase C inhibitor, exerts antipsychotic-like effects in animal models. Prog Neuropsychopharmacol Biol Psychiatry 35:1636-1644

Raj VP, Chandrasekhar RH, Vijayan P, Dhanaraj SA, Rao MC, Rao VJ, Nitesh K (2010) In vitro and in vivo hepatoprotective effects of the total alkaloid fraction of Hygrophila auriculata leaves. Indian J Pharmacol 42:99-104

Shanmugasundaram P, Venkataraman S (2006) Hepatoprotective and antioxidant effects of Hygrophila auriculata (K. Schum) Heine Acanthaceae root extract. J Ethnopharmacol 104:124-128

Shi S, Zhao Y, Zhou H, Zhang Y, Jiang X, Huang K (2008) Identification of antioxidants from Taraxacum mongolicum by high-performance liquid chromatography-diode array detection-radical-scavenging detectionelectrospray ionization mass spectrometry and nuclear magnetic resonance experiments. J Chromatogr A 1209:145-152

Shimosaki S, Tsurunaga Y, Itamura H, Nakamura M (2011) Anti-allergic effect of the flavonoid myricitrin from Myrica rubra leaf extracts in vitro and in vivo. Nat Prod Res 25:374-380

Son YO, Lee SA, Kim SS, Jang YS, Chun JC, Lee JC (2011) Acteoside inhibits melanogenesis in B16F10 cells through ERK activation and tyrosinase downregulation. J Pharm Pharmacol 63:1309-1319

Sudha CG, Seeni S (1994) In vitro multiplication and field establishment of Adhatoda beddomei C. B. Clarke, a rare medicinal plant. Plant Cell Rep 17:203-207

Thomas TD, Yoichiro H (2010) In vitro propagation for the conservation of a rare medicinal plant Justicia gendarussa Burm. f. by nodal explants and shoot regeneration from callus. Acta physiol plant 32:943-950
Vijayakumar M, Govindarajan R, Rao GM, Rao Ch V, Shirwaikar A, Mehrotra S, Pushpangadan P (2006) Action of Hygrophila auriculata against streptozotocin-induced oxidative stress. J Ethnopharmacol 104:356-361

Yamada P, lijima R, Han J, Shigemori H, Yokota S, Isoda H (2010) Inhibitory effect of acteoside isolated from Cistanche tubulosa on chemical mediator release and inflammatory cytokine production by RBL-2H3 and KU812 cells. Planta Med 76:1512-1518

Yamamura S, Ozawa K, Ohtani K, Kasai R, Yamasaki K (1998) Antihistaminic flavones and aliphatic glycosides from Mentha spicata. Phytochemistry 48:131-136

Zhao J, Liu T, Ma L, Yan M, Zhao Y, Gu Z, Huang Y (2009) Protective effect of acteoside on immunological liver injury induced by Bacillus Calmette-Guerin plus lipopolysaccharide. Planta Med 75:1463-1469

Zou J, Zhu YD, Zhao WM (2008) Two new alkyl glycosides from Clerodendranthus spicatus. J Asian Nat Prod Res 10:602-606

Zou GA, Su ZH, Zhang HW, Wang Y, Yang JS, Zou ZM (2010) Flavonoids from the stems of Croton caudatus Geisel. var. tomentosus Hook. Molecules 15:1097-1102

doi:10.1186/1999-3110-54-51

Cite this article as: Ho et al:: Chemical and pharmacological investigation of micropropagated Hygrophila pogonocalyx produced from leaf explants. Botanical Studies 2013 54:51.

\section{Submit your manuscript to a SpringerOpen ${ }^{\circ}$ journal and benefit from:}

- Convenient online submission

- Rigorous peer review

- Immediate publication on acceptance

- Open access: articles freely available online

- High visibility within the field

- Retaining the copyright to your article

Submit your next manuscript at $\gg$ springeropen.com 